\title{
Human Cytomegalovirus: detection of congenital and perinatal infection in Argentina
}

\author{
Angélica Lidia Distéfano*, Alicia Alonso, Fabián Martin and Fabián Pardon
}

Address: Department of Virology, Laboratorio de Virosis Congénitas Perinatales y Transmisión Sexual, Instituto Nacional de Microbiología INEIANLIS "Carlos G. Malbrán". Ministerio de Salud de la Nación, Av. Vélez Sársfield 563. CP 1281. Buenos Aires. Argentina

Email: Angélica Lidia Distéfano* - adistefano@anlis.gov.ar; Alicia Alonso - aalonso@anlis.gov.ar; Fabián Martin - fmartin@anlis.gov.ar; Fabián Pardon - fpardon@anlis.gov.ar

* Corresponding author

Published: 23 June 2004

BMC Pediatrics 2004, 4:II doi:I0.| | 86/|47|-243|-4-I I
Received: 23 September 2003

Accepted: 23 June 2004

This article is available from: http://www.biomedcentral.com/I47/-243 I/4/II

(C) 2004 Distéfano et al; licensee BioMed Central Ltd. This is an Open Access article: verbatim copying and redistribution of this article are permitted in all media for any purpose, provided this notice is preserved along with the article's original URL.

\begin{abstract}
Background: Human cytomegalovirus (CMV) is one of the most commonly found agents of congenital infections. Primary maternal infection is associated with risk of symptomatic congenital diseases, and high morbidity is frequently associated with very low birth weight. Neonates with asymptomatic infection develop various sequelae during infancy. This is the first Argentine study performed in neonates with congenital and postnatal HCMV infection. The purpose of this study was to evaluate the performance of the polymerase chain reaction (PCR) technique with different pairs of primers, to detect cytomegalovirus isolated in tissue cultures and directly in urine and dried blood spot (DBS) specimens. Results were compared with IgM detection.
\end{abstract}

Methods: The study was performed between 1999 and $200 \mathrm{I}$ on routine samples in the Laboratory. A total of 6I urine and 56 serum samples were selected from 61 newborns/infants, 33 patients whose samples were analyzed during the first two to three weeks of life were considered congenital infections; the remaining 28 patients whose samples were taken later than the third week were grouped as perinatal infections, although only in 4 the perinatal transmission of infection was determined unequivocally

Cytomegalovirus diagnosis was made by isolating the virus from urine samples in human foreskin fibroblast cells.

Three different primer pairs directed to IE, LA and gB genes were used for the HCMV PCR assay in viral isolates. Subsequently, PCR and nested PCR (nPCR) assays with gB primers were performed directly in urine and in II samples of dried blood spot (DBS) on Guthrie Card, these results were then compared with serology.

Results: The main clinical manifestations of the 33 patients with congenital infection were purpura, jaundice, hepatomegaly and anaemia. Three patients presented low birth weight as single symptom, 10, intracranial calcifications, and 2 , kidney failure. In the 28 patients grouped as with perinatal infection, anaemia, hepatosplenomegaly and enzymatic alteration were predominant, and 4 patients were HIV positive.

The primers used to amplify the gB region had a PCR positivity rate of $100 \%$, whereas those that amplified IE and LA regions had a PCR positivity rate of $54 \%$ and $61 \%$ respectively, in CMV isolates.

Amplification by PCR of urine samples (with no previous DNA extraction), using primers for the gB region, detected 34/ 61 positive samples. Out of the 33 samples from patients with congenital infection, 24 (73\%) were positive. When nPCR was used in these samples, all were positive, whereas in the remaining 28 patients, two negative cases were found.

Cytomegalovirus DNA detection in II samples was also carried out in DBS: 7 DBS samples were positive and 4 were negative. 
Conclusions: Primers directed to the gB fragment region were the best choice for the detection of CMV DNA in positive isolates. In congenital infections, direct PCR in urine was positive in a high percentage (73\%) of samples; however, in patients grouped as with perinatal infection only $36 \%$ of the cases were positive. With n-PCR, total sample positivity reached $97 \%$. PCR technique performed in DBS allowed identifying congenital infection in four patients and to be confirmed in 3. These results show the value of $\mathrm{nPCR}$ for the detection of all cases of CMV infection. The assay offers the advantage that it may be performed within the normal working day and provides reliable results in a much shorter time frame than that required for either traditional tissue culture or the shell-viral assay.

\section{Background}

Human cytomegalovirus (CMV) is the viral agent most frequently associated with congenital infections in man. Although $90 \%$ of CMV congenitally infected infants are asymptomatic at birth, approximately 10\% develop cytomegalic inclusion diseases, with a 20-30\% mortality rate [1]. However, up to age 2, 10-15\% of asymptomatic children develop neurological sequelae [2], such as sensorineural hearing loss, mental retardation, motor deficits, seizures and chorioretinitis. CMV has been observed in infants born to mothers who were seropositive before pregnancy $[3,4]$. Postnatal disease, though generally asymptomatic, frequently occurs in infants with hepatic involvement.

Several epidemiological studies on the incidence of the virus and the long-term sequelae of congenital CMV infection have been carried out in the United States, UK and Italy [5-7].

A vaccine against CMV is currently under development $[8,9]$, and new antiviral therapy for symptomatic newborns is under study [10].

Detection of CMV DNA by PCR amplification contributes to a rapid and early diagnosis [11]. A large variety of primers have been used for the detection of CMV DNA by PCR, but the problem to select suitable primers has prompted studies in several laboratories, because the variations in the viral genome sequence found in strains circulating in diverse populations have been shown to affect the ability of the reaction to detect CMV DNA $[1,12,13]$.

We analysed the efficacy of three sets of primers that amplify three different regions of $\mathrm{CMV}$ genomes for the early diagnosis of CMV infections in a selected group of 61 newborns with congenital or perinatal infection. The best conditions in terms of primers, to confirm the clinical suspicion of congenital or postnatal CMV infection, can be established by tests on CMV isolates or by direct work on urine samples. We performed the test on CMV isolates with $80 \%$ of cytopathic effect to standardise the method and ensure enough viral DNA so that PCR amplification would not be conditioned by this factor. The results herein presented allowed the selection of suitable $\mathrm{gB}$ primers for PCR of urine and DBS samples and their correlation with serology data.

\section{Methods \\ Population}

Sixty-one patients with positive virological results were selected from a group of 237 newborns with signs and symptoms compatible with HCMV diseases. Only 3 out of 33 congenital infection patients had low body weight as sole symptom (Table 1 ). The series consisted of urine and serum samples from 61 patients. Samples for congenital infection diagnosis were collected at 1-21 days, and for perinatal infection at $4.5 \pm 3.5$ months. Both samples were collected simultaneously. CMV infection was confirmed by urine cultures performed during routine activities at our laboratory. Dried blood spots (DBS) were collected from 11 babies, 3 during the early days of life, and from the remaining 8 , who were studied retrospectively, at 24 days, 40 days, 34 days, 3 months, 2 at 5 months, 8 months and 20 months.

Congenital infection was diagnosed in 33 cases, while the 28 remaining cases were grouped as perinatal infections, althugh they should be conceptually grouped as "congenital or perinatal" infections, since in only 4 cases could the perinatal origin of the infection be demonstrated by analysing two samples, one taken at the time of birth and the other when the disease was clinically manifest.

Virological Methods: Urine samples were processed in parallel by PCR and culture, DBS by PCR and serum was tested by solid-phase enzymatic immunoassay (Organon Teknika).

\section{Processing of clinical samples \\ Isolation of CMV in cell cultures and confirmation by an indirect immunofluorescence test}

Two to $10 \mathrm{ml}$ of urine were collected in sterile bags. A portion was tested by culture and the rest was stored at $-20^{\circ} \mathrm{C}$ for direct PCR (with no previous DNA extraction).

For isolation of CMV, urine samples were pre-filtered through $0.2-\mu \mathrm{m}$ membranes, and inoculated $(200 \mu \mathrm{l})$ in PTP monolayers, a human foreskin fibroblast cell line established by the Service of Tissue Culture (INEI, ANLIS 
Table I: Clinical findings in $6 \mathrm{I}$ infants with congenital and perinatal infection and specific IgM antibodies to Cytomegalovirus detected by enzymoimmunoassay

\begin{tabular}{|c|c|c|c|}
\hline $\begin{array}{l}\text { Congenital } \\
\text { Patient No }\end{array}$ & Age (day/month) & $\lg M$ & Clinical and Laboratory data \\
\hline 1 & $5 d$ & + & IUGR, cerebral calcifications. \\
\hline 2 & $21 d$ & - & Ascites, renal problems, elevated liver enzymes. \\
\hline 3 & $6 d$ & + & SGA, purpura, hepatosplenomegaly \\
\hline $4,8,29$ & $5 d, 5 d, 28 d$ &,,-++ & SGA \\
\hline 5 & $18 d$ & + & Petechiae, hepatosplenomegaly, jaundice \\
\hline $6,14 ., 32$ & $5 \mathrm{~d}, 8 \mathrm{~d}, 8 \mathrm{~d}$ &,,+++ & Hepatosplenomegaly, cerebral calcifications \\
\hline 7 & $14 \mathrm{~d}$ & + & Sepsis, thrombocytopenia. \\
\hline 9 & $20 \mathrm{~m}$ & - & AWGA, purpura, elevated liver enzymes. \\
\hline 10 & $5 d$ & + & SGA, cerebral microcalcifications, microcephaly \\
\hline 11 & $5 d$ & - & SGA, purpura, hepatosplenomegaly, thrombocytopenia \\
\hline 12 & $4 d$ & - & AWGA, purpura, elevated liver enzymes, trombocytopenia. \\
\hline 13 & II d & + & Sepsis, petechiae, thrombocytopenia \\
\hline $15,21,33$ & $5 d, 5 d, 5 d$ &,,-+- & SGA, purpura, HIV+. \\
\hline 16 & $6 d$ & - & Cerebral calcifications, thrombocytopenia, HIV+ mother. \\
\hline 17 & $5 d$ & + & Foetal dystrophy, inclusion-bearing cells in urine. \\
\hline 18 & $14 d$ & $\mathrm{~S} / \mathrm{s}$ & IUGR, sepsis, foetal dystrophy \\
\hline 19 & $8 \mathrm{~d}$ & + & Hepatosplenomegaly, sepsis, died of hepatic failure \\
\hline 20 & $18 \mathrm{~d}$ & + & SGA, hydrocephalus, respiratory problems \\
\hline 22 & $3 \mathrm{~m}$ & $\mathrm{~S} / \mathrm{s}$ & Cerebral calcifications, congenital toxoplasmosis \\
\hline 23 & $24 d$ & - & Cholestasis, purpura, cerebral calcifications, elevated liver enzymes, sepsis. \\
\hline 24 & $5 d$ & - & Microcephaly, cerebral calcifications (irregular and punctate), thrombocytopenia \\
\hline 25 & $5 d$ & + & AWGA, hepatosplenomegaly, sepsis, jaundice. \\
\hline 26 & $3 \mathrm{~m}$ & - & Chorioretinitis \\
\hline 27 & $5 d$ & - & SGA, hepatosplenomegaly, petechiae, anaemia, cholestasis \\
\hline 28 & $5 \mathrm{~d}$ & + & SGA, purpura, cerebral calcifications, thrombocytopenia, splenomegaly, elevated liver enzymes \\
\hline 30 & $5 \mathrm{~d}$ & + & Hepatosplenomegaly, purpura \\
\hline 31 & $5 \mathrm{~m}$ & - & RNPT, AWGA, seizures, maturational delay, palsy at age one year \\
\hline \multicolumn{4}{|r|}{ 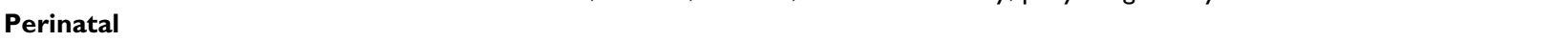 } \\
\hline 39 & $40 \mathrm{~d}$ & - & SGA, petechiae, hepatomegaly, respiratory problems. \\
\hline 41 & $5 \mathrm{~m}$ & + & $\mathrm{HIV}+$, cerebral calcifications, hepatosplenomegaly, anaemia \\
\hline 47 & $34 \mathrm{~d}$ & + & Neonatal jaundice \\
\hline 50 & $8 \mathrm{~m}$ & - & SGA, Hepatosplenomegaly, elevated liver enzymes, anaemia, jaundice at age 2 months \\
\hline \multicolumn{4}{|c|}{ Congenital or Perinatal } \\
\hline $34,37,48$ & $3 \mathrm{~m}, 8 \mathrm{~m}, 7 \mathrm{~m}$ &,,$-- S / s$ & Hepatosplenomegaly, HIV+ \\
\hline 35 & $4 \mathrm{~m}$ & + & Jaundice, biliary atresia \\
\hline 36 & $63 d$ & + & Anaemia, hepatosplenomegaly, malnutrition, hyperbilirubinemia \\
\hline 38,43 & $4 \mathrm{~m}, 3 \mathrm{~m}$ &,-- & Petechiae, hyperbilirubinemia, splenomegaly \\
\hline 40 & $40 d$ & - & Ascitis, renal problems, elevated liver enzymes \\
\hline 42 & $42 d$ & $\mathrm{~S} / \mathrm{s}$ & SGA \\
\hline 44 & $3 \mathrm{~m}$ & + & Premature, scanty maternal contact \\
\hline 45 & $24 \mathrm{~m}$ & - & Malnutrition, pancytopenia. \\
\hline 46 & $12 \mathrm{~m}$ & + & Aplastic crisis \\
\hline 49 & $4 \mathrm{~m}$ & + & SGA, hepatosplenomegaly, jaundice, anaemia, petechiae. \\
\hline 51 & $2 \mathrm{~m}$ & + & Sepsis, cyanosis, vomiting \\
\hline 52 & $\mathrm{~lm}$ & $\mathrm{~S} / \mathrm{s}$ & Petechiae, jaundice, anaemia, hepatosplenomegaly \\
\hline 53 & $5 \mathrm{~m}$ & + & Mental retardation, anaemia \\
\hline 54 & $2 \mathrm{~m}$ & - & RNPT, SGA, IUGR, anaemia, microcephaly, tricuspid valve insufficiency \\
\hline 55 & $3 \mathrm{~m}$ & - & SGA, rash, fever spikes \\
\hline 56,58 & $5 \mathrm{~m}, 33 \mathrm{~d}$ &,-- & SGA, respiratory problems. \\
\hline 57 & $34 \mathrm{~d}$ & + & IUGR, sepsis, hepatomegaly, oesophageal atresia, elevated liver enzymes \\
\hline 59 & $26 \mathrm{~d}$ & - & SGA, HIV+ mother \\
\hline 60 & $38 \mathrm{~d}$ & + & IUGR, microcephaly, jaundice \\
\hline 61 & $6 \mathrm{~m}$ & - & Normal at birth, neutropenia \\
\hline
\end{tabular}

IUGR, intrauterine growth retardation; SGA, small for gestational age; AWGA, adequate weight for gestational age. S/s, sera not collected 
Dr. Carlos G. Malbrán). Eagle's minimum essential medium (Gibco) containing 2\% foetal calf serum (Gibco) was used to maintain the cell line. A 200- $\mu$ l aliquot was inoculated on a confluent monolayer of fibroblasts, and then incubated at $37^{\circ} \mathrm{C}$ for up to 3 weeks. Eagle's was replaced every 7 days, and fibroblasts were examined every $48 \mathrm{~h}$ until appearance of typical viral cytopathic effect. Positive cultures were suspended, washed with phosphate buffer (PBS) and fixed with acetone. For direct immunofluorescence, cells were incubated at $37^{\circ} \mathrm{C}$ for 45 min using a monoclonal antibody to $\mathrm{CMV}$ late antigen (Whittaker, Bioprod and Chemicon Intl.), and washed. Later, they were incubated at $37^{\circ} \mathrm{C}$ for $30 \mathrm{~min}$ in FITClabelled, anti-mouse rabbit serum (Dako), washed again, and then observed by fluorescence microscopy.

\section{Serology}

The presence of CMV-IgM antibody was determined by an enzyme-linked immunoabsorbent assay (Vironostika anti-CMV IgM II, Organon Teknika), according to the manufacturer's instructions.

\section{CMV-PCR}

Sample preparation

Tissue culture

CMV isolates with $80 \%$ of cytopathic effect in PTP cells were treated with Trypsin-Versene, washed and suspended in maintenance medium (MM). For DNA release, $1 \mathrm{ml}$ of this suspension was heated at $55^{\circ} \mathrm{C}$ for $60 \mathrm{~min}$ and then at $100^{\circ} \mathrm{C}$ for $7 \mathrm{~min}$, and further centrifuged at $10,000 \mathrm{rpm}$ for $3 \mathrm{~min}$. The supernatant was transferred to another Eppendorf tube and frozen at $-80^{\circ} \mathrm{C}$ for at least 1 hour. Thus, it could be used as a template for PCR.

\section{Urine}

$5 \mu$ l of each urine sample were directly amplified by nPCR (with no previous DNA release), with the primers directed to the $\mathrm{gB}$ region. Negative samples were diluted with sterile deionized water $(50 \%)$, in order to dilute inhibitors [1].

\section{Blood Spots}

The extraction of CMVDNA in DBS on Guthrie Cards obtained from 11 neonates was performed following the method of Shibata et al. [14] with the modifications introduced by M. Barbi et al. [15].

\section{Reaction}

The PCR method for the detection of CMV was carried out with previously described oligonucleotide primers for the major immediate-early (MIE) fragment region (IV exon de IE1, $242 \mathrm{pb}[1,15]$, glycoprotein B (gB) gene (ORF UL55), $150 \mathrm{pb}[11,16,17]$, and late antigen (LA) (ppUL83), 400 $\mathrm{pb}[1]$.
Table 2 shows the sequences of the oligonucleotide primers herein used. Reaction mixtures consisted of $5 \mu \mathrm{l}$ of target DNA, 10 pmol of each oligonucleotide primer, for LA primers $2.5 \mathrm{U} / \mu \mathrm{l}$ of enzyme Taq polymerase (PerkinElmer Cetus, Nowalk) and $2.0 \mathrm{U} / \mu \mathrm{l}$ for $\mathrm{gB}$ and IE primers, $200 \mu \mathrm{M}$ (each) of deoxynucleotide triphosphate, $5 \mu \mathrm{l}$ of $10 \mathrm{X}$ reaction buffer $(500 \mathrm{mM} \mathrm{KCl}, 10 \mathrm{mM}$ tris- $\mathrm{HCl}, \mathrm{pH}$ $8.3,1.5 \mathrm{mM} \mathrm{MgCl}_{2}, 0.01 \%$ gelatin), and high-pressure liquid chromatography distilled water to a total volume of $50 \mu \mathrm{l}$ in an Eppendorf tube. A negative control reaction tube received only $50 \mu \mathrm{l}$ of reaction mixture. A positive control was carried out with the pattern strain kindly provided by Dr. María Barbi from the Istituto di Virologia, Università degli Studi di Milano. Different cycles of amplification were carried out using a DNA thermocycler (GeneAmp 2400, Perking-Elmer Cetus). Amplification conditions were those described by the authors, with only minor changes: region LA, 40 cycles of denaturation at $94^{\circ} \mathrm{C}$ for $105 \mathrm{sec}$, annealing at $65^{\circ} \mathrm{C}$ for $75 \mathrm{sec}$ and extension at $72^{\circ} \mathrm{C}$ for $60 \mathrm{sec}$; each extension period was increased by $10 \mathrm{sec}$ on each subsequent cycle; region $\mathrm{gB}$, 35 cycles of denaturation at $94^{\circ} \mathrm{C}$ for $15 \mathrm{sec}$, annealing at $58^{\circ} \mathrm{C}$ for $15 \mathrm{sec}$ and extension $72^{\circ} \mathrm{C}$ for $15 \mathrm{sec}$; the second amplification differed from the first in that 30 cycles were performed and the annealing temperature was $50^{\circ} \mathrm{C}$; region IE, 35 cycles of denaturation at $94^{\circ} \mathrm{C}$ for $15 \mathrm{sec}$ annealing at $55^{\circ} \mathrm{C}$. for $15 \mathrm{sec}$ and extension $72^{\circ} \mathrm{C}$ for 15 sec. One initial denaturation at $94^{\circ} \mathrm{C}, 2 \mathrm{~min}$ and one final extension at $72^{\circ} \mathrm{C}, 5 \mathrm{~min}$ were carried out in all amplifications.

Aliquots $(18 \mu \mathrm{l})$ of each PCR-amplified product were electrophoresed on 2\% agarose gel (Sigma A-7431) containing $0.5 \mu \mathrm{g} / \mathrm{ml}$ of ethidium bromide and were visualised and photographed with UV light (Fig. 1).

\section{Specificity of $P C R$ reaction}

These primers have previously failed to amplify other herpes viruses and cellular DNA.

\section{$P C R$ positivity rates of reaction}

To estimate the PCR positivity rates, with the primers gB, IE and LA relative to tissue culture, cells infected with the pattern strain (Towne) were allowed to develop up to $80 \%$ cytopathic effect, and released DNA (as described in sample preparation) was analysed by undiluted PCR and with $1 / 50,1 / 100,1 / 200,1 / 300$ and $1 / 400$ dilutions.

\section{Results}

\section{PCR positivity rates}

Primers gB were amplified up to $1 / 300$ dilution, primers IE up to $1 / 100$ and LA up to $1 / 50$. 
Table 2: Sequences of oligonucleotide primers used for the amplification of HCMV genome

\begin{tabular}{lllll}
\hline Primers & Sequence (5-3)' & Product Length $\mathbf{( p b )}$ & Position in the gene & References \\
\hline IE & $\begin{array}{l}\text { tgaggataagcgggagatgt } \\
\text { actgaggcaagttctgcagt }\end{array}$ & 242 & $\begin{array}{l}1729-1748 \\
1951-1970\end{array}$ & Jiwa N et al. (1989) \\
gB & $\begin{array}{l}\text { Outer } \\
\text { accaccgcactgaggaatgtcag } \\
\text { tcaatcatgcgtttgaagaggta }\end{array}$ & 150 & $1942-1966$ & Darlington et al. (1985) \\
& $\begin{array}{l}\text { inner } \\
\text { accaccgcactgaggaatgtcag } \\
\text { tcaatcatgcgttgaagaggta } \\
\text { cacctgtcaccgctgctatattgc } \\
\text { caccacgcagcggcccttgatgttt }\end{array}$ & 100 & $2067-2091$ & \\
& 400 & $1967-1989$ & Demmler G et al. (1998) \\
\hline
\end{tabular}

\section{MIE gB LA MIE gB LA} MIE gB LA MIE gB LA

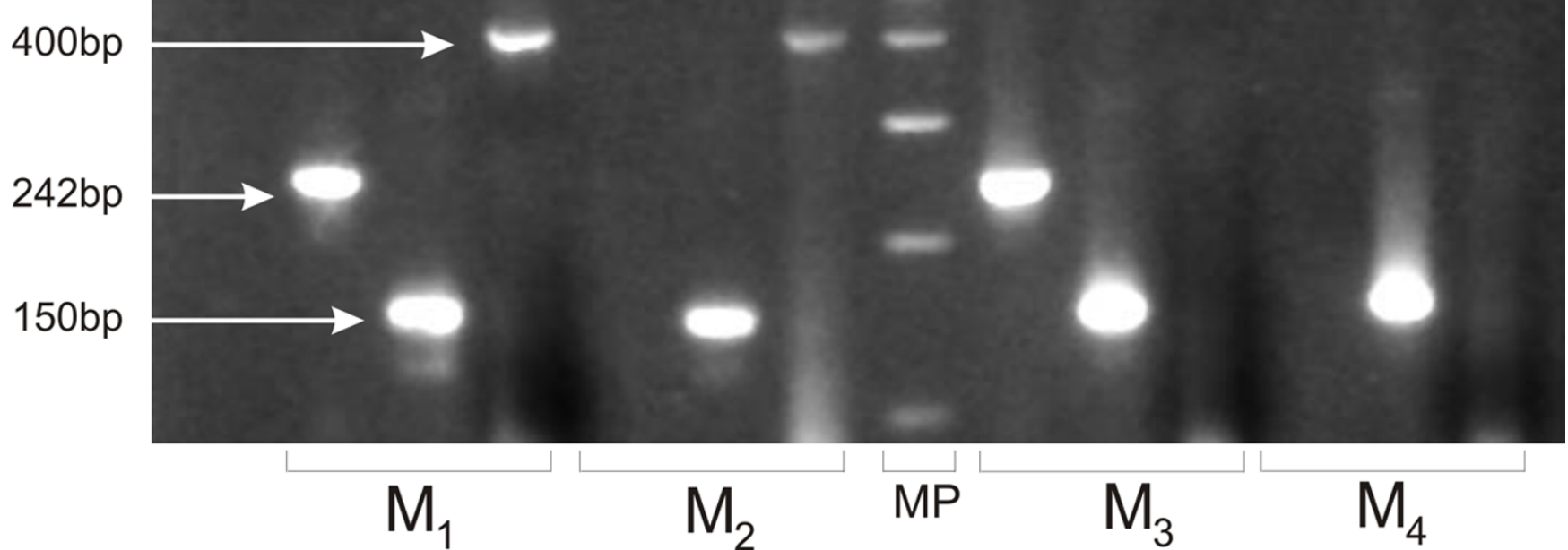

Figure I

Ethidium bromide-stained agarose gel electrophoresis: analysis of DNA amplified with primers MIE, gB, LA. Samples (M) the different newborns (MI, M2, M3, M4). MP 100 bp DNA marker 
Table 3: Detection of HCMV by PCR/nPCR with gB primers in CMV isolates and urine

\begin{tabular}{|c|c|c|c|c|}
\hline Samples & Methods & infection & Positive (\%) & Total positive (\%) \\
\hline \multirow[t]{2}{*}{ Positive culture } & PCR & Congenital & $33(100)$ & $61(100)$ \\
\hline & & Perinatal $* *$ & $28(100)$ & \\
\hline \multirow[t]{2}{*}{ Urine } & $\begin{array}{l}\text { Direct PCR without DNA } \\
\text { release }\end{array}$ & Congenital & $24(73)$ & $34(56)$ \\
\hline & & Perinatal** & $10(36)$ & \\
\hline \multirow[t]{2}{*}{ Urine } & $n-P C R$ & Congenital & $33(100)$ & $59(97)$ \\
\hline & & Perinatal** & $26(93)^{*}$ & \\
\hline
\end{tabular}

* from the 3 negative samples, one of which became positive when a dilution was made ** samples grouped as perinatal

\section{$P C R$ from $C M V$ isolates}

PCR from CMV positive cultures with $\mathrm{gB}$ primers were positive in oll cases, unlike primers directed to the other regions (Fig. 1); gB primer amplified 61/61 samples; IE 33/61 (12 congenital and 21 out of those grouped and LA $37 / 61$ (19 congenital and 18 out of those grouped. Thus, the PCR positivity rates of primers was $100 \%$ for $\mathrm{gB}, 54 \%$ for IE, and $61 \%$ for LA.

\section{$P C R$ of urine samples using primers for the $g B$ region}

Definite PCR results using primers that amplify the $\mathrm{gB}$ region in positive cell cultures was higher (61/61) than those obtained by direct PCR (with no previous DNA release) in urine samples from the same patients: 34/61 (56\%), although 24 out of 33 patients with congenital infection (73\%) were positive (Table 3 ). When nPCR was used in the same samples, $100 \%$ of patients with congenital infection and 26 (93\%) with samples grouped as perinatal infection were positive (Table 2 ).

$P C R$ of $(D B S)$ using primers for the $g B$ region

Out of the 11 patients studied, 3 were newborn (pts. 6, 10 and 24), and out of the remaining 8, four aged, 20 months, 3 months, 24 days, and 5 months (pts. 9, 22, 23, and 31 ) were positive, while the other four aged 40 days, 5 months, 34 days and 8 months (pts. 39, 41, 47 and 50) were negative.

\section{Discussion}

Out of a group of 237 children of CMV infection, 61 samples were selected with positive isolation, 33 of which presented congenital infection, while the remaining 28 were grouped as perinatal infection; although in only 4 could perinatal infection be demonstrated and the other 24 could be either perinatal or congenital. The frequency of positive cases in laboratory tests carried out was 14\% (33/ 237). of children with congenital infection, $4.66 \%$ annual. This is a high frequency because the patients came from a population of low economic resources with a high seroprevalence of IgG for CMV, a result only explained by the fact that all cases reaching our laboratory come from suspected patients [18].

Amplification by PCR is frequently used in diagnostic laboratories for the detection of CMV. As the choice of PCR primers for $\mathrm{CMV}$ is crucial, three primer pairs were selected from the literature, the IE and LA [1-12], which amplify fragments of the early and late regions of the genome respectively; and the $\mathrm{gB}[11,16,17]$, which amplifies a fragment of the region that encodes the glycoprotein $B$. These primers were designed from the pattern strains AD169 and Towne, and they amplify genome regions that are considered conserved, due to their functional properties. In order to unify the conditions of amplification, CMV DNA extracted from cultures with an $80 \%$ of viral cytopathic effect was used in all cases.

Several authors have found that the exon 4 region of the IE gene was highly variable, and that nucleotide substitution was distributed along the gene $[19,20]$. These variations would result in alterations in the aa sequence of 12 positions (13\%). The biological meaning of these variations is yet unknown.

Fewer studies have been conducted on LA primers. In 1988, Shibata et al. [21] amplified 28 samples of viral isolates positive for CMV by PCR using IE and LA primers. They found that one sample was amplified by the IE primers but not by the LA, whereas the other sample was amplified by the LA primer but not by the IE.

In this study, the efficacy of LA primers in amplifying samples from newborns was higher than that of IE primers ( $61 \%$ and 54\%, respectively). Although these primers are the most frequently used for laboratory diagnosis, the results herein obtained indicate that their use is not advisable for the newborn population.

Differences in the PCR positivity rates of detection of the viral genome among samples of patients studied by diverse authors and those included in our study were 
probably due to the design of the primers. Even though sensitivity with the diverse primers is variable $(\mathrm{gB} 1 / 300$, IE 1/100, LA 1/50), this factor would be negligible when using an excess of virus unless the DNA release method were efficient enough. Another factor to be considered is that the number of passages in cell culture of viral isolates analysed by PCR is too low to cause variations that could affect the PCR reaction in conserved DNA sequences. Sequencing of the IE and LA region of those strains that failed to be amplified by the primers would confirm this hypothesis.

In samples from studied patients, the PCR positivy rates for $\mathrm{gB}$ with $\mathrm{CMV}$ isolates was $100 \%$ compared with the gold-standard (tissue culture). Since gB primers were the most suitable for the study of congenital infection in Argentina, we attempted to determine whether these primers were also effective when direct amplification (with no previous DNA release) of urine samples was performed in our patients. Viral genome was found in all samples by nPCR (Table 3 ) but positive results were found by PCR in $56 \%$ (34 patients) of the cases, including two asymptomatic patients. On the other hand, in 33 congenital infection patients, positive results were observed in $73 \%$ (24 patients), so that we may infer that in most cases of congenital infection in symptomatic patients, CMV infection may be detected by a single amplification in urine. In these patients grouped as perinatal infection there were three negative samples: one became positive after dilution, and the other two were negative. This could be associated with low viral elimination, sample alteration during shipping or presence of inhibitory factors in urine, since no purification was used. Samples from 11 patients were studied by DBS PCR at the time of birth, 8 of which were evaluated retrospectively, thus allowing the congenital source of infection to be determined in four cases. Likewise, 4 cases of perinatal infection were confirmed by this same technique.

Serology is a technique widely used in most laboratories, despite its low sensitivity [18-22], so that it has also been included in this study in order to discern the sensitivity of the serological method used in our laboratory. However, there were no significant differences between the serology in patients with congenital infection and those grouped as perinatal. Therefore, an accurate diagnostic method such as PCR is highly advisable for the management of congenital infection in new-borns during the first three weeks of life. Viral isolation is very limited in our country due the expense of specialised labour and the need of a special tissue culture laboratory, so that PCR provides a valid alternative.

Finally, given the large size of the CMV genome, and despite the homogeneity among clinical isolates, sequence studies should comprise more strains. More importantly, there must be consensus on the type of primers to be used, since it has been demonstrated that slight and sometimes silent variations in the sequence may alter PCR sensitivity, thus leading to misdiagnoses.

\section{Competing interests}

None declared.

\section{Authors' contributions}

ALD designed the study, wrote the paper and carried out PCR studies. FM performed the serological study, FP the virological study and AA performed the statistical analysis.

\section{Acknowledgements}

This study was supported by the Instituto Nacional de Microbiología INEIANLIS "Carlos G. Malbrán".

We thank Dr. Guadalupe Carballal for her critical comments. Dr. Maria Barbi (Institute of Virology at the University of Milan) gave us encouragement and provided us with the pattern strain. We also thank Cecilia Gonzalez for her excellent technical assistance.

\section{References}

I. Demmler GJ, Buffone GJ, Schimbor CM, May RA: Detection of Cytomegalovirus in urine from newborns by using polymerase chain reaction DNA amplification. J Infect Dis 1988 , I 58(6): | | 77- I | 84.

2. Fowler KB, McCollister FP, Dahle AJ, Boppana S, Britt WJ, Pass RF: Progressive and fluctuating sensorineural hearing loss in children with asymptomatic congenital cytomegalovirus infection. J Pediatr 1997, 4:624-630.

3. Morris DJ, Sims D, Chiswick M, Das VK, Newton VE: Symptomatic congenital cytomegalovirus infection after maternal recurrent infection. Pediatr Infect Dis J I994, I 3:6 I-64.

4. Boppana SB, Rivera LB, Fowler KB, Mach M, Britt WJ: Intrauterine transmission of cytomegalovirus to infants of women with preconceptional immunity. $N$ Engl J Med 200I, 344( I 8): I 366- I37I.

5. Murph JR, Souza IE, Dawson JD, Benson P, Petheram SJ, Pfab D, Gregg A, O'Neill ME, Zimmerman B, Bale JF: Epidemiology of congenital cytomegalovirus infection: maternal risk factors and molecular analysis of cytomegalovirus strains. Am J Epidemiol 1998, I 47( I 0):940-947.

6. Griffiths PD, Baboonian C, Rutter D, Peckham C: Congenital and maternal cytomegalovirus infections in a London population. Br J Obstet Gynaecol I991, 98(2): I35-I40.

7. Barbi M, Binda S, Primache V, Clerici D, for the NEOCMV Group: Congenital cytomegalovirus infection in a northern Italian region. Eu J of Epidemiol 1998, 00:000-000.955-960.

8. Plotkin SA: Vaccination against cytomegalovirus, The Changeling Demon. Pediatr Infect Dis J 1999, 1 8:313-326.

9. Gonczol E, Plotkin SA: Development of a cytomegalovirus vaccine: lessons from recent clinical trials. Expert Opin Biol Ther 200I, I(3):40I-4I2.

10. Whitley RJ, Cloud G, Gruber W, Storch GA, Demmler GJ, Jacobs RF, Dankner W, Spector SA, Starr S, Pass RF, Stagno S, Britt WJ, Alford C, Soong S-J, Zhou X-J, Sherrill L, FitzGerald JM, Sommadossi JP: Ganciclovir treatment of symptomatic congenital cytomegalovirus infection: results of a phase II study. National Institute of Allergy and Infectious Diseases. Collaborative Antiviral Study Group. J Infect Dis I997, I 75(5): I080-1086.

II. Coyle PV, Wyatt DE, Ong GM, Maxwell AP, McCaughey C, O'Neill $\mathrm{HJ}$ : A nested primer set targeting the cytomegalovirus glycoprotein B gene. J Clin Virol 2002, 25:95-96.

12. Mendez JC, Espy MJ, Smith TF, Wilson JA, Paya CV: Evaluation of PCR primers for early diagnosis of Cytomegalovirus infection following liver transplantation. J Clin Microbiol 1998, 36(2):526-530. 
13. Zweygberg Wirgart B, Brytting M, Linde A, Wahren B, Grillner L: Sequence variation within three important cytomegalovirus gene regions in isolates from four different patient populations. J Clin Microbiol I 998, 36(I 2):3662-3669.

14. Shibata M, Takano H, Hironaka T, Hirai K: Detection of human cytomegalovirus DNA in dried newborn blood filter paper.J Virol Methods 1994, 46:279-285.

15. Jiwa NM, Van Gemert GW, Raap AK, Van de Rijke FM, Mulder A, Lens PF, Salimans MM, Zwaan FE, Van Dorp W, Van Der Ploeg M: Rapid detection of human cytomegalovirus DNA in peripheral blood leukocytes of viremic transplant recipients by the polymerase chain reaction. Transplantation 1989, 48(I):72-76.

16. Barbi M, Binda S, Primache V, Caroppo S, Didò P, Guidotti P, Corbetta C, Melotti D: Cytomegalovirus DNA detection in Guthrie cards: a powerful tool for diagnosing congenital infection. J Clin Virol 2000, I7:159-165.

17. Darlington J, Super M, Patel K, Grundy JE, Griffiths PD, Emery VC: Use of the polymerase chain reaction to analyse sequence variation within a major neutralizing epitope of glycoprotein B (gp58) in clinical isolates of human cytomegalovirus. J Gen Virol 1991, 72(8): 1985-1989.

18. Revello MG, Gerna G: Diagnosis and management of human cytomegalovirus infection in the mother, fetus, and newborn infant. Clin Microbiol Rev 2002, I5(4):680-7I5.

19. Brytting M, Wahlberg J, Lundeberg J, Wahren B, Uhlen M, Sundqvist $\mathrm{V}$ : Variations in the cytomegalovirus major immediate-early gene found by direct genomic sequencing. J Clin Microbiol 1992, 30(4):955-960.

20. Chou S: Effect of Interstrain variation on diagnostic DNA amplification of the cytomegalovirus major immediate-early gene region. I Clin Microbiol I 992, 30(9):2307-23 I0.

21. Shibata D, Martín WJ, Appleman MD, Causey DM, Leedom JM, Arnhein N: Detection of cytomegalovirus DNA in peripheral blood of patients infected with human immunodeficiency virus. J Infect Dis 1988, I 58(6): I 185-I 192.

22. Revello MG, Zavattoni M, Baldanti F, Sarasini A, Paolucci S, Gerna G: Diagnostic and prognostic value of Human Cytomegalovirus load and IgM antibody in blood of congenitally infected newborns. J Clin Virol 1999, 14:57-66.

\section{Pre-publication history}

The pre-publication history for this paper can be accessed here:

http://www.biomedcentral.com/1471-2431/4/11/prepub

\section{Publish with Bio Med Central and every scientist can read your work free of charge}

"BioMed Central will be the most significant development for disseminating the results of biomedical research in our lifetime. "

Sir Paul Nurse, Cancer Research UK

Your research papers will be:

- available free of charge to the entire biomedical community

- peer reviewed and published immediately upon acceptance

- cited in PubMed and archived on PubMed Central

- yours - you keep the copyright

Submit your manuscript here:

http://www.biomedcentral.com/info/publishing_adv.asp
BioMedcentral 